\title{
Involvement of a Metalloprotease in Low-Affinity Nerve Growth Factor Receptor Truncation: Inhibition of Truncation in vitro and in vivo
}

\author{
Peter S. DiStefano, Diane M. Chelsea, Christine M. Schick, and Jeffrey F. McKelvy \\ Neuroscience Research Division, Abbott Laboratories, Abbott Park, Illinois 60064
}

The mechanism of low-affinity NGF receptor (LNGFR) truncation was investigated in cultured Schwann cells. Affinity labeling of Schwann cells with ${ }^{125}$ |-NGF or metabolic labeling with ${ }^{35}$ S-cysteine showed that truncated NGF receptor (NGFRt) was derived from the cell surface form of the receptor. Addition of full-length, exogenous NGF receptor $\left(M_{r}=80\right.$ $\mathrm{kDa}$ ) to Schwann cell membranes resulted in cleavage of the exogenous substrate to NGF-Rt. Investigations into the mechanism of truncation revealed that metalloprotease inhibitors such as phenanthroline, bathophenanthroline, and 8-hydroxyquinoline (8-OHQ) blocked LNGFR truncation in a concentration-dependent fashion. Inhibitors of other protease classes had no effect on truncation. In addition, truncation did not occur at $4^{\circ} \mathrm{C}$. It was found that truncation could also occur in Schwann cell membrane preparations, indicating that the putative protease was membrane bound and closely associated with the LNGFR. Metal reconstitution experiments revealed a strong preference toward zinc for the truncating activity, with iron and manganese having slight reconstitution activity in phenanthroline-quenched membranes. To determine if apparent truncation could be inhibited in vivo, the metalloprotease inhibitor 8-OHQ was administered to neonatal rats. 8-OHQ resulted in decreased urine and blood NGF-Rt levels and increased the sciatic nerve LNGFR content; this effect was dose dependent. In adult rats with sciatic nerve crush lesions, 8-OHQ (30-300 $\mathbf{m g} / \mathbf{k g}$, t.i.d.) significantly enhanced the rate of sensory neuron regeneration as assessed by the nerve pinch assay. This was accompanied by increased levels of LNGFR in distal nerve segments.

These results suggest that Schwann cells possess a metalloprotease-like activity that serves to cleave LNGFR from the surface of these cells. We propose that the putative metalloprotease represents a novel mechanism by which the Schwann cell regulates this particular cell surface protein. Furthermore, increasing the amount of Schwann cell surface LNGFR appears to be of functional significance in that sensory nerve regeneration can be enhanced by inhibition of truncation.

[Key words: low-affinity NGF receptor, truncation, metalloprotease, enzyme Inhlbition, development, regeneration]

\footnotetext{
Received Aug. 21, 1992; revised Nov. 24, 1992; accepted Dec. 8, 1992.

Correspondence should be addressed to Peter S. DiStefano, Ph.D., Neurobiology, Regeneron Pharmaceuticals, Inc., 777 Old Saw Mill River Road, Tarrytown, NY 10591-6707.

Copyright (c) 1993 Society for Neuroscience $0270-6474 / 93 / 132405-10 \$ 05.00 / 0$
}

The developmental regulation of low-affinity NGF receptors (LNGFRs) on Schwann cells raises questions as to the physiological role of these binding sites on peripheral glia. Studies have shown that LNGFRs are present in high concentrations in prenatal and neonatal peripheral nerve and that levels of receptor decline with development, such that adult nerve maintains very low levels of the receptor (Yan and Johnson, 1987). Similarly, Schwann cells isolated from embryonic day 18 (E18) sciatic nerve contain severalfold more NGF binding sites than their postnatal day 3 (P3) counterparts (DiStefano and Johnson, 1988a). Following lesion of adult peripheral nerve, LNGFR is reexpressed on all Schwann cells distal to the site of lesion (Taniuchi et al., 1986; Heumann et al., 1987b). It has been proposed (Johnson et al., 1988) that loss of axonal contact signals the Schwann cell to synthesize LNGFR for the purpose of binding, and thus sequestering NGF (produced in part by Schwann cells) on the Schwann cell surface, forming a permissive environment for NGF-dependent axons to grow through. This model may be tenable for both developing and regenerating axons. The fact that NGF binding sites on Schwann cells are of the low-affinity form, and do not internalize bound NGF (DiStefano and Johnson, 1988a), strongly suggests that NGF receptors are present on Schwann cells for the benefit of developing or regenerating axons. However, Schwann cell LNGFR may play a role in cell adhesion, Schwann cell migration (Anton and Matthew, 1992), or modulation of signal transduction.

In addition to this unique expression and regulation of LNGFR on the Schwann cell surface, it has recently been shown that Schwann cells shed a truncated form of the NGF receptor (NGF$\mathrm{Rt}$ ) into their extracellular space (DiStefano and Johnson, 1988b). NGF-Rt has a net molecular weight of $\sim 50 \mathrm{kDa}$ compared to $75-80 \mathrm{kDa}$ for the cell surface receptor. It is LNGFR-like by virtue of the fact that it specifically binds NGF and is recognized by the anti-rat LNGFR monoclonal antibody 192-IgG (DiStefano and Johnson, 1988b). In addition, the amino terminus of NGF-Rt purified from human amniotic fluid is identical to that deduced from the cDNA for human LNGFR and suggests a truncation site at or near the transmembrane region of the molecule (Zupan et al., 1989). In vitro, pure Schwann cell cultures shed increasing amounts of NGF-Rt into their medium with time. Several other LNGFR-bearing cells also shed NGF$\mathrm{Rt}$ in culture, but not to the extent of Schwann cells. In vivo, NGF-Rt is found in the plasma and the urine of neonatal rats in extremely high levels. NGF-Rt is developmentally regulated in that urine and plasma levels of the shed receptor decline very rapidly after birth $\left(t_{1 / 2}=4-7 \mathrm{~d}\right)$, reaching $5 \%$ of P1 levels at 4 
weeks of age. A similar developmental regulation has been demonstrated for human NGF-Rt (DiStefano et al., 1991). Following adult rat sciatic nerve transection, NGF-Rt is increased threeto fourfold $1 \mathrm{~d}$ after lesion and remains elevated for 2 weeks postaxotomy. We postulate that NGF-Rt regulation follows that of LNGFR on the Schwann cell surface during the course of development and during regeneration (DiStefano and Chelsea, 1990).

The physiological significance of LNGFR truncation remains unclear. Perhaps one way to understand how this protein functions is to inhibit the truncation process and observe the cellular and functional consequences of inhibiting NGF-Rt production. In the present study we have examined the effects of various protease inhibitors on LNGFR truncation in Schwann cells in an attempt to identify the class of protease involved in truncation of the LNGFR to NGF-Rt. Our results provide evidence that a metalloprotease is involved in the truncation of LNGFR. Furthermore, inhibition of the putative metalloprotease activity in vivo enhances the regeneration rate of peripheral sensory neurons. We propose that INGFR truncation represents a novel means of regulating the Schwann cell surface content of LNGFR during development and regeneration.

\section{Materials and Methods}

\section{Materials}

Carrier-free $\mathrm{Na}^{125} \mathrm{I}(100 \mathrm{mCi} / \mathrm{ml})$ was purchased from Amersham (Arlington Heights, IL). The following compounds were purchased from Sigma (St. Louis, MO): Ala-Ala-Phe-chloromethylketone (Ala-Ala-PheCMK), bathophenanthroline, bestatin, bovine serum albumin (BSA), carbobenzoxy (Cbz)-Gly-Phe, diisopropylfluorophosphate (DFP), dithiothreitol, ethylenediamine tetra-acetate (EDTA), 8-hydroxyquinoline hemisulfate (8-OHQ), iodoacetamide, leupeptin, phenylmethylsulfonyl fluoride (PMSF), 1,10-phenanthroline, phosphoramidon. Thiorphan was purchased from Bachem Bioscience (Philadelphia, PA). Ethyldimethylamino carbodiimide (EDAC) was from Pierce (Rockford, IL). Collagenase was purchased from Worthington (Freehold, NJ). Sodium pentobarbital was obtained from Abbott Laboratories (Abbott Park, IL). All other reagents were of analytical grade and purchased from standard chemical sources.

\section{Methods}

Schwann cell cultures. Schwann cells were isolated from the sciatic nerves of E21 rats as described (DiStefano and Chelsea, 1990). Cells were plated in $25 \mathrm{~cm}^{2}$ flasks for 3-5 d before use in experiments. It has been determined that after this time in culture LNGFRs are highly expressed on the Schwann cell surface and that truncation is fully evident (DiStefano and Johnson, 1988a,b).

Affinity labeling of Schwann cells with ${ }^{125} I-N G F$. NGF was radioiodinated to specific activities of $1500-2900 \mathrm{cpm} / \mathrm{fmol}$ by the lactoperoxidase method as described (Marchalonis, 1969; Yip and Johnson, 1983). Schwann cells were harvested and washed in phosphate-buffered saline containing $0.1 \%$ BSA (PBS/BSA). Normally, 6-8 $\times 10^{6}$ cells were resuspended in $1 \mathrm{ml}$ of PBS/BSA to which was added $1 \mathrm{ml}$ of ${ }^{125}$ I-NGF to a final concentration of 4-8 nM. After binding for $20 \mathrm{~min}$ at $23^{\circ} \mathrm{C}, 1$ mM EDAC (final concentration) was added and the NGF was crosslinked to Schwann cell LNGFR on ice for $20 \mathrm{~min}$. The cross-linking reaction was quenched by the addition of $12 \mathrm{ml}$ of PBS/BSA containing $20 \mathrm{~mm}$ glycine for $10 \mathrm{~min}$ on ice. Cells were centrifuged and resuspended in normal Schwann cell medium (Dulbecco's Modified Eagle Medium, $10 \%$ fetal calf serum). Five hundred microliter aliquots of cells containing $5 \times 10^{5}$ cells were added to 24 well culture dishes (Falcon), and incubated for $0-24 \mathrm{hr}$ at $37^{\circ} \mathrm{C}$ in a humidified atmosphere containing $5 \% \mathrm{CO}_{2}$. Various protease inhibitors were added as $100 \times$ stock solutions immediately after cell plating. In some experiments, cells were placed at $4^{\circ} \mathrm{C}$ to assess the effects of temperature on NGF-Rt formation. Initial studies showed that, following this labeling procedure, Schwann cells attached to the dish $1 \mathrm{hr}$ after replating. At $24 \mathrm{hr}$ cells were morphologically and metabolically intact as assessed by phase-contrast microscopy and ${ }^{35} \mathrm{~S}$-methionine incorporation in cells cross-linked to unlabeled NGF (data not shown). After the various incubation times cells were placed on ice and media were removed. Media were centrifuged $15,000 \times g$ for $10 \mathrm{~min}$, and the supernatant was removed and stored at $-80^{\circ} \mathrm{C}$. The cells were washed, manually scraped from the dishes in $0.5 \mathrm{ml}$ of PBS/BSA on ice, and pelleted by centrifugation at $12,000 \times$ $g$ for $1 \mathrm{~min}$. Cells were stored at $-80^{\circ} \mathrm{C}$ until immunoprecipitation of LNGFR and NGF-Rt species (see below).

Metabolic labeling of Schwann cells. Schwann cells were plated $(5 \times$ $10^{3}$ cells) in $35 \mathrm{~mm}$ culture dishes and washed $1 \mathrm{hr}$ in cysteine-free medium. Cells were pulsed for $4 \mathrm{hr}$ with $0.5 \mathrm{mCi}$ of ${ }^{35} \mathrm{~S}$-cysteine (Amersham, Arlington Heights, IL) in normal medium containing one-third the normal cysteine content. Cells were chased with $2 \times$ cysteine medium for 0-24 hr. In other experiments cells were chased for $4 \mathrm{hr}$ in the presence or absence of various protease inhibitors. Following the chase periods, cells and media were collected and stored as described above.

Preparation of affinity-labeled Schwann cell membranes. Schwann cells were affinity labeled as described above and osmotically shocked in $400 \mu \mathrm{l}$ of ice-cold $20 \mathrm{~mm}$ phosphate buffer, $\mathrm{pH} \mathrm{7.4}$. Cells were further disrupted by $3 \times 2 \mathrm{sec}$ blasts with a cell sonicator. The resulting membranes were centrifuged $700 \times g$ for 10 min to pellet nuclei, large debris, and unlysed cells. The resulting supernatant was centrifuged $50,000 \times$ $g$ for $20 \mathrm{~min}$ in a Beckman TL- 100 rotor. The pelleted membranes were resuspended in PBS/BSA on ice; $200 \mu \mathrm{l}$ aliquots were incubated with or without inhibitors for $4 \mathrm{hr}$ at $37^{\circ} \mathrm{C}$. Following this incubation membranes were centrifuged at $106,000 \times g$ for $20 \mathrm{~min}$. Membranes and supernatants were stored at $-80^{\circ} \mathrm{C}$ until immunoprecipitation of LNGFR and NGF-Rt, respectively.

Immunoprecipitation of NGF receptor species. Cells and membranes containing LNGFR were solubilized in $2 \%$ octylglucoside in $0.5 \mathrm{M} \mathrm{NaCl}$ and $0.5 \%$ sucrose, $\mathrm{pH} 7.4$, for $1 \mathrm{hr}$ at $4^{\circ} \mathrm{C}$. Samples were clarified by centrifugation at $15,000 \times g$ for $10 \mathrm{~min}$. Samples containing LNGFR and NGF-Rt were incubated with 192-IgG (Chandler et al., 1984) and the 192-IgG-receptor complexes precipitated with rabbit anti-mouse IgG adsorbed to Staphylococcus aureus cells (Pansorbin, BoehringerMannheim). Precipitates were boiled in SDS containing $2 \%$ mercaptoethanol, and ${ }^{125}$ I-NGF receptor species were visualized by SDS-acrylamide gel electrophoresis (SDS-PAGE) as described (DiStefano and Johnson, 1988a,b). For metabolic labeling studies, immunoprecipitates were washed twice in standard RIPA buffer, and visualized by fluorography. The intensities of gel bands associated with LNGFR or NGFRt were quantified using an LKB Ultroscan XL laser densitometer. Arbitrary densitometric units are expressed as percentage of control (PBS) treated samples.

SCG-conditioned medium experiments. Schwann cells and Schwann cell membranes were prepared from $\mathrm{P} 1$ mice as described for the rat. Rat superior cervical ganglion (SCG)-conditioned medium (SCG-CM), which contains a whole $(\sim 80 \mathrm{kDa})$, soluble form of the LNGFR (DiStefano and Johnson, 1988b) was incubated with mouse Schwann cells or mouse Schwann cell membranes for $0-24 \mathrm{hr}$ at $37^{\circ} \mathrm{C}$. Media from membrane and whole-cell experiments were prepared as described above and stored at $-80^{\circ} \mathrm{C}$. Affinity labeling of soluble receptor species with ${ }^{125}$ I-NGF followed by EDAC cross-linking, 192-IgG immunoprecipitation, and SDS-PAGE was carried out (DiStefano and Johnson, 1988 b) to identify whole and truncated NGF receptor species in the conditioned media following incubations with whole Schwann cells or membranes.

Ion reconstitution experiments. Schwann cell membranes were affinity labeled as described above and incubated with $1 \mathrm{~mm}$ phenanthroline for $1 \mathrm{hr}$ at $4^{\circ} \mathrm{C}$ to quench metalloprotease activity. The membranes were washed and resuspended in PBS/BSA containing $3 \times 10^{-3} \mathrm{M}$ concentrations of zinc, iron, calcium, magnesium, manganese, or copper as the chloride or sulfate salts. Truncation was allowed to occur at $37^{\circ} \mathrm{C}$ for 4 $\mathrm{hr}$, at which time the samples were chilled to $4^{\circ} \mathrm{C}$ and centrifuged 106,000 $\times g$ for 20 min. NGF receptor species were immunoprecipitated with 192-IgG and visualized on 10\% acrylamide gels as described above. Results were quantified densitometrically and expressed as the ratio of NGF-Rt:LNGFR (medium:membrane-associated receptor).

In vivo studies: neonates. 8-Hydroxyquinoline hemisulfate (8-OHQ) was dissolved in distilled water, filtered through a $0.2 \mu$ filter, and injected subcutaneously into P1 rats (Sasco, Madison, WI) at doses of $25,50,75$, and $100 \mathrm{mg} / \mathrm{kg}$ three times daily for $3 \mathrm{~d}$. At this time rats were decapitated and trunk blood was collected in heparinized tubes; urine was also collected and pooled within the various treatment groups. A $1.0 \mathrm{~cm}$ section of sciatic nerve from each side was also harvested. NGF-Rt in blood and urine was estimated and quantified as described (DiStefano and Johnson, 1988b). Sciatic nerve NGF receptor was assayed by the method of Yan and Johnson (1987) and expressed as 


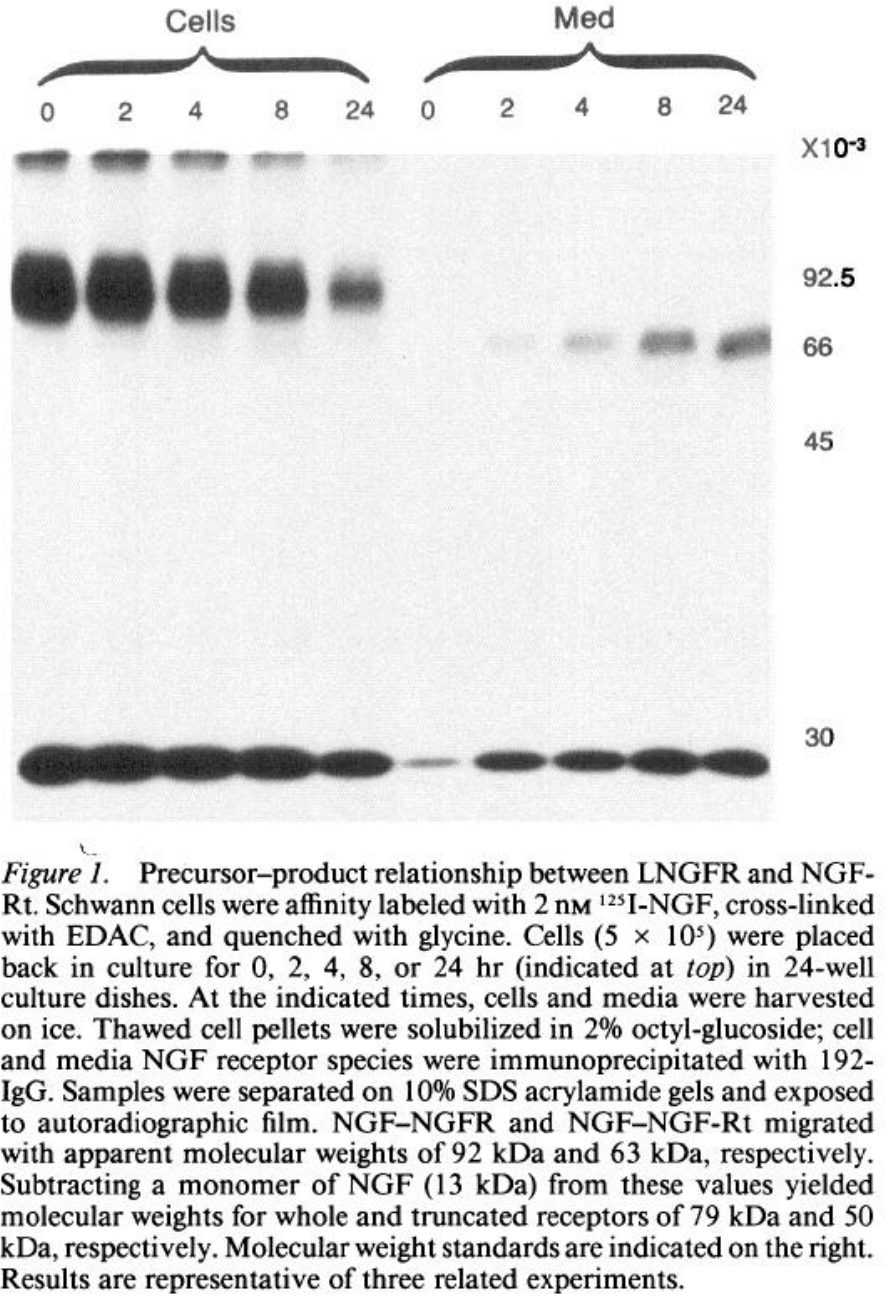

femtomoles of ${ }^{125} \mathrm{I}-\mathrm{NGF}$ cross-linked/mg of nerve protein. Truncated and whole nerve NGF receptor levels from treated rats were compared to vehicle-treated littermates.

In vivo studies: adults. Male Sprague-Dawley rats weighing 225-250 gm were purchased from Sasco, housed individually for $7 \mathrm{~d}$ prior to an experiment, and given food and water ad libitum. Rats were anesthetized with $50 \mathrm{mg} / \mathrm{kg}$ sodium pentobarbital, and a crush lesion was performed on the right sciatic nerve at the level of the tendon of the obturator internus muscle. The crush was made uniformly by compressing the nerve for $10 \mathrm{sec}$ with a \#5 jeweler's forceps using a hemostat compressed to the first notch. Overlying muscle and dermis were sutured and the animals allowed to recover $2-11 \mathrm{~d}$ in initial experiments. At various times, nerves were exposed, the crush site identified, and the distance of sensory regeneration determined using the nerve pinch test as described (Young and Medawar, 1940; McQuarrie et al., 1977). Persons performing the pinch tests were blinded to the treatment of the animals. A second, blinded observer verified the scoring of the pinch test. Distances of sensory nerve regeneration with time (rate) were compared in rats receiving $50-300 \mathrm{mg} / \mathrm{kg}$ of $8-\mathrm{OHQ}$ three times daily (s.c.) versus vehicle (sterile, distilled water). Initially, regeneration distances were monitored over 2-8 d following crush. For dose-response studies regeneration rates were monitored at $3 \mathrm{~d}$ postcrush, as both LNGFR mRNA (Heumann et al., 1987a) and LNGFR protein (Taniuchi et al., 1986) are significantly elevated in distal nerve at this time. In other groups of lesioned rats treated with $8-\mathrm{OHQ}, 8 \mathrm{~mm}$ portions of nerve representing the 4-12 $\mathrm{mm}$ of distal nerve (and corresponding regions of contralateral nerve) were removed from rats and assayed for LNGFR content as described (Yan and Johnson, 1987).

For all in vivo experiments animals were handled and cared for according to the Guide for the Care and Use of Laboratory Animals (NIH Publication 86-23, 1985).

Statistics. Statistically significant differences between various in vitro

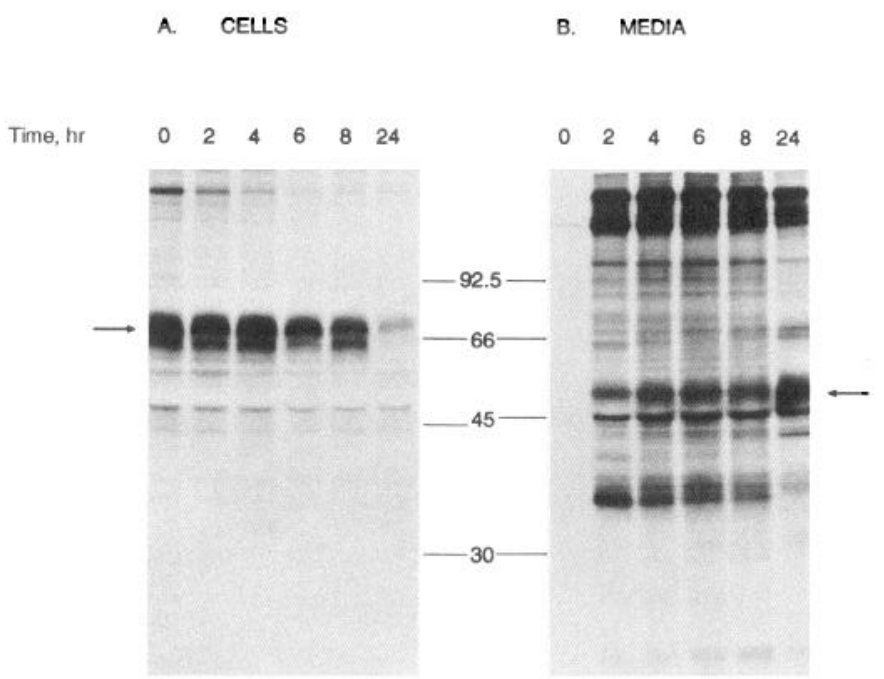

Figure 2. Precursor-product relationship between LNGFR and NGF$\mathrm{Rt}$ as determined by metabolic labeling/pulse-chase experiments. Schwann cells $\left(1 \times 10^{6}\right)$ were plated in $35 \mathrm{~mm}$ dishes and pulse-labeled for $4 \mathrm{hr}$ at $37^{\circ} \mathrm{C}$ with $0.5 \mathrm{mCi}$ of ${ }^{35} \mathrm{~S}$-cysteine, followed by washing and replacement with normal Schwann cell medium containing a $2 \times$ cysteine content for $0,2,4,6,8$, and $24 \mathrm{hr}$ (indicated at top). Cells $(A)$ and media $(B)$ were harvested on ice at the indicated time points as described for Figure 1. Cell extracts and conditioned media were processed for 192-IgG immunoprecipitation. Proteins were separated on $10 \%$ gels and processed for fluorography. Cell surface (whole) and truncated NGF receptors migrated with apparent molecular weights of $\sim 75 \mathrm{kDa}$ and $\sim 50 \mathrm{kDa}$, respectively. Molecular weight standards (in thousands) are indicated between $A$ and $B$. Arrow in $A$ indicates LNGFR; arrow in $B$ indicates NGF-Rt.

and in vivo experimental groups were determined by analysis of variance (ANOVA), followed by Dunnett's or Student-Newman-Keuls' post hoc analysis. Significant differences between means were tested at the 0.05 and 0.01 level.

\section{Results}

To measure the relative amount of LNGFR truncation, assays were developed where Schwann cell surface LNGFR was affinity labeled with ${ }^{125} \mathrm{I}-\mathrm{NGF}$, or metabolically labeled with ${ }^{35} \mathrm{~S}-\mathrm{cys}-$ teine. Cells and conditioned media were followed over time for the diminution of cell-associated LNGFR labeling and the appearance of NGF-Rt in the medium. Figure 1 shows that when ${ }^{125} \mathrm{I}-\mathrm{NGF}$-labeled Schwann cells were placed back in culture, the cell surface (whole) receptor content decreased over a $24 \mathrm{hr}$ period. Inversely, there was no NGF-Rt in the medium of these cultures at time zero; NGF-Rt was detected in the media at 2$4 \mathrm{hr}$ and increased further with time in culture. This precursorproduct relationship was also observed under conditions where LNGFR was metabolically labeled with ${ }^{35} \mathrm{~S}$-cysteine in pulsechase experiments (Fig. 2). For both methods the half-life of LNGFR on the cell surface was approximately $8-12 \mathrm{hr}$. These results suggest that NGF-Rt is derived from the cell surface form of the receptor, and provide a reproducible means to quantify changes in Schwann cell NGF-Rt formation with various manipulations.

If Schwann cells contain an LNGFR-cleaving activity it stands to reason that exogenously added LNGFR (substrate) should be cleaved by Schwann cells or fractions thereof. To address this, mouse Schwann cells and Schwann cell membranes were incubated with rat SCG-CM, which contains readily detectable 


\section{A. SCHWANN CELLS}

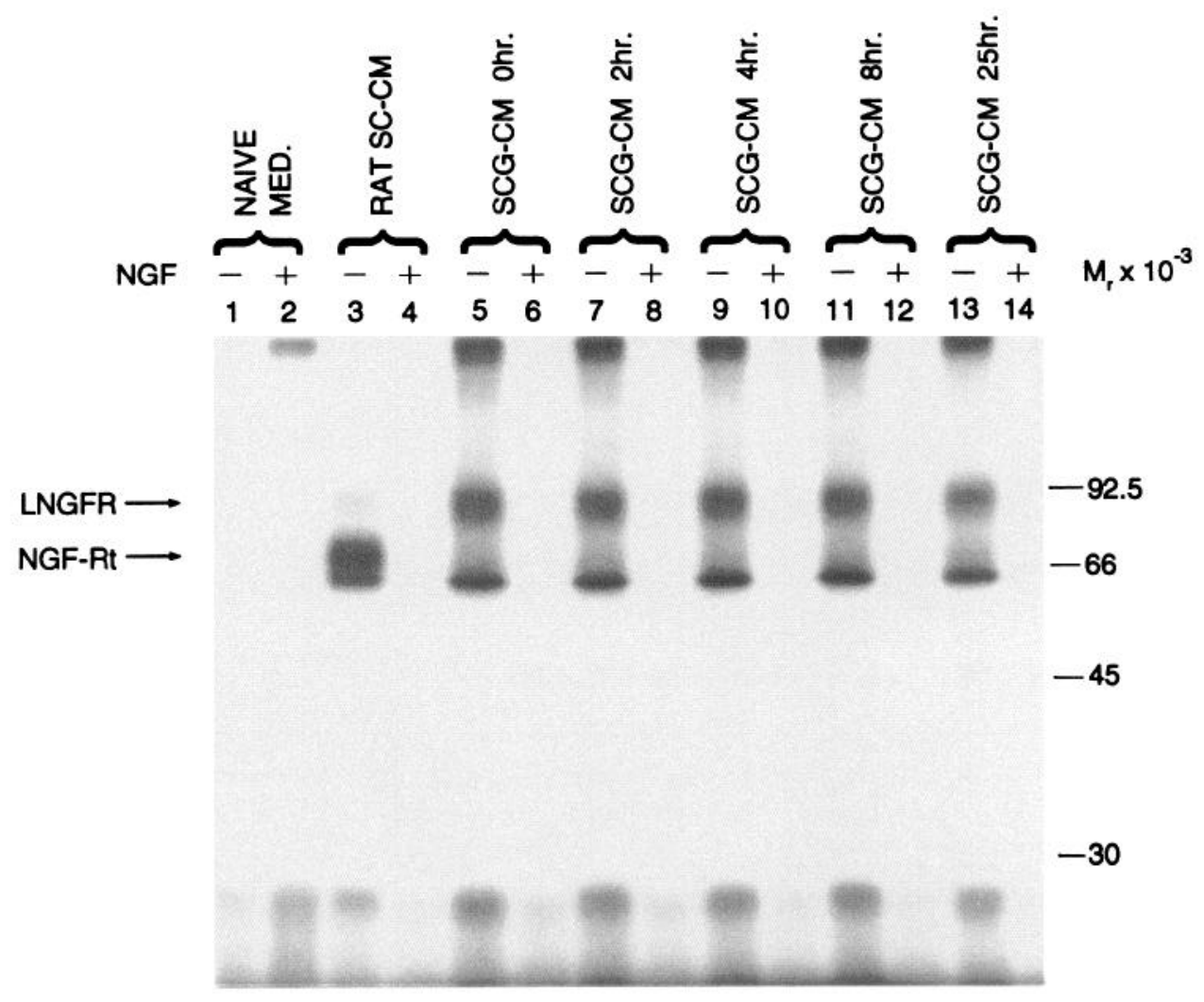

B. SCHWANN CELL MEMBRANES

Figure 3. Ability of Schwann cells or Schwann cell membranes to cleave exogenously added LNGFR substrate. Rat SCG-CM was added to mouse Schwann cells $(A)$ or mouse Schwann cell membranes $(B)$ for $0,2,4,8$, or $25 \mathrm{hr}$ at $37^{\circ} \mathrm{C}$. Media in $A$ were harvested as in Figure 1. Membranes were separated from media by ultracentrifugation at $106,000 \times g$ for $20 \mathrm{~min}$. Total and nonspecific binding of ${ }^{125}$ I-NGF to conditioned or naive media samples was estimated by binding in the absence $(-)$ or presence $(+)$ of a 300 -fold excess of unlabeled NGF. Samples were separated on $10 \%$ gels and exposed to autoradiographic film (molecular weight standards to the right). Arrows indicate positioning of LNGFR (top arrow) and NGF-Rt (bottom arrow). $S C$ - CM, Schwann cell-conditioned medium.

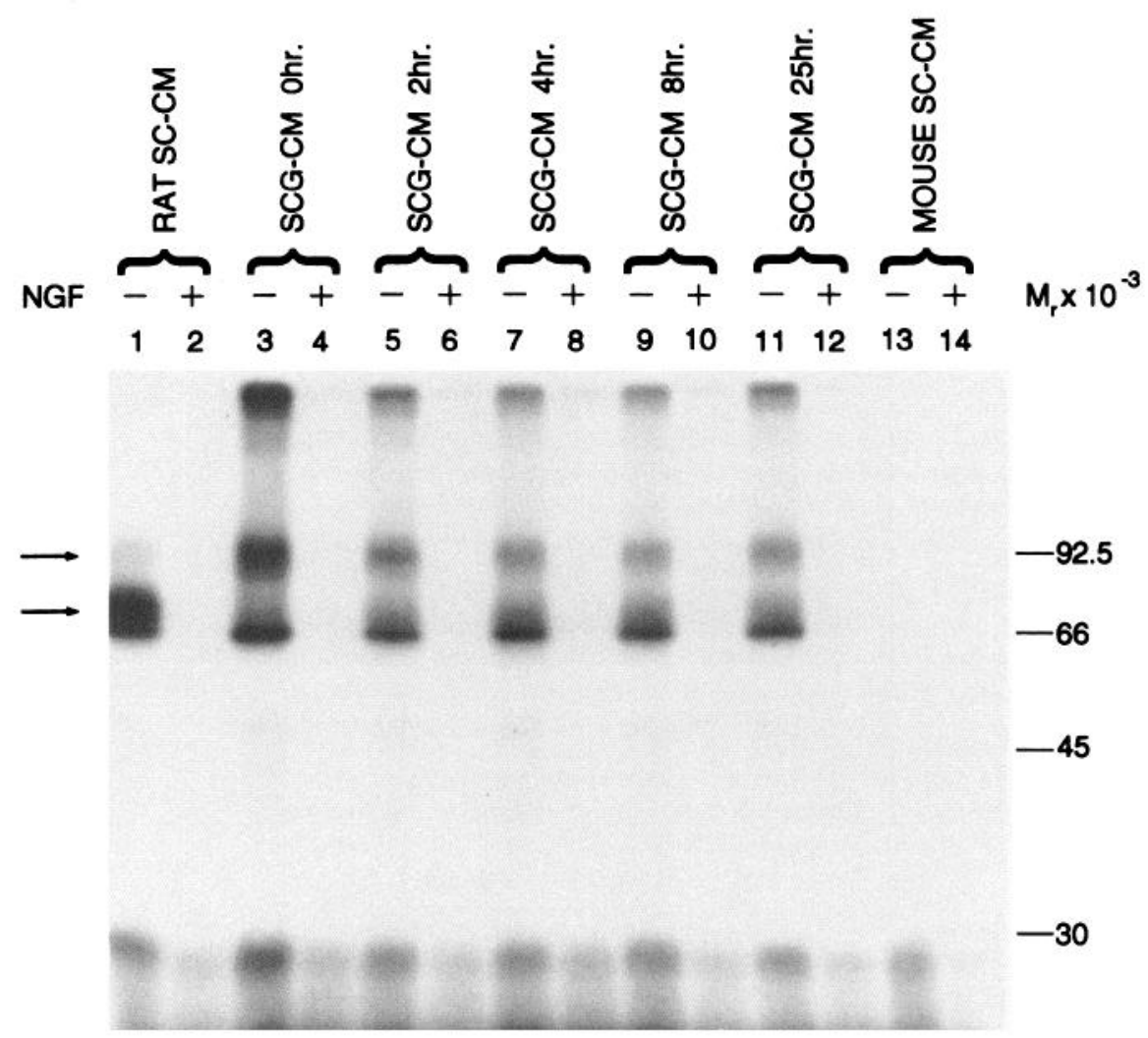


A.

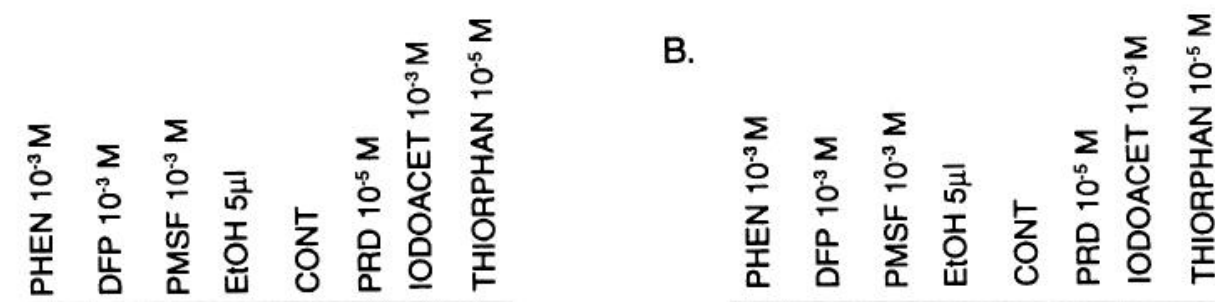

Figure 4. Effect of phenanthroline and various other protease inhibitors on LNGFR truncation in whole Schwann cells. $A$, medium NGF-Rt; $B$, cell surface LNGFR. Schwann cells were affinity labeled with ${ }^{125} \mathrm{I}-\mathrm{NGF}$ and placed back in culture for $4 \mathrm{hr}$ at $37^{\circ} \mathrm{C}$ in the presence or absence of the indicated inhibitors (indicated at top). Phenanthroline was dissolved in 25\% ethanol; PMSF and DFP were dissolved in 100\% ethanol. All other inhibitors were dissolved in aqueous buffers. Cells and media were harvested on ice and prepared for 192-IgG immunoprecipitation as described for Figure 1. Samples were separated on $10 \%$ gels and subjected to autoradiography. Molecular weight standards $\left(M_{r} \times 10^{-3}\right)$ are indicated between $A$ and $B . P H E N$, phenanthroline; $D F P$, diisopropylfluorophosphate; $P M S F$, phenylmethylsulfonyl fluoride; $E t O H$, ethanol; $C O N T$, control/PBS; $P R D$, phosphoramidon; $I O$ $D O A C E T$, iodoacetamide. amounts of whole LNGFR (DiStefano and Johnson, 1988b). After incubation with cells or membranes, the NGF receptor species in the media were identified as described in Materials and Methods. The rationale for using mouse Schwann cells (and membranes) and rat SCG-CM was that $192-\mathrm{IgG}$ recognized only rat NGF receptor. Thus, mouse Schwann cell NGF receptor would not be recognized in the assay and would not be visualized on the resulting gel autoradiograms. Figure $3 A$ shows that if SCG-CM was incubated with whole mouse Schwann cells little if any cleavage of LNGFR to recognizable NGF-Rt occurred (lanes 5-14). However, if the same experiment was carried out with mouse Schwann cell membranes, LNGFR was converted to NGF-Rt as early as $2 \mathrm{hr}$ after incubation, increasing through 8-24 hr of incubation (Fig. 3B, lanes 3-12). In controls for this experiment, naive medium, not exposed to SCG cultures (Fig. $3 A$, lanes 1,2 ), and mouse Schwann cell-conditioned medium (Fig. $3 B$, lanes 13,14 ) had no $192-$ IgG-precipitable activity. These results show that exogenous substrate (whole LNGFR) can be cleaved by the source of the putative enzyme, namely, membranes prepared from Schwann cells.

To investigate possible proteolytic mechanisms involved in LNGFR truncation, Schwann cells were affinity labeled and placed back in culture for $4 \mathrm{hr}$ in the presence or absence of various protease inhibitors. Figure $4 A$ and Table 1 show that phenanthroline blocked the appearance of NGF-Rt in the medium in a concentration-dependent fashion, while causing an increased accumulation of cell surface (whole) LNGFR (Fig. $4 B$ ). The serine protease inhibitors DFP and PMSF were without effect, as was the thiol protease inhibitor iodoacetamide (Fig. 4). The diphenyl derivative of phenanthroline, bathophenanthroline, and 8-OHQ also effectivcly blocked truncation; however, other known metalloprotease inhibitors, such as EDTA, phosphoramidon, thiorphan, and peptide-based inhibitors, had no effect on truncation in whole cells. In fact, Ala-Ala-Phe-CMK and Cbz-Gly-Phe appeared to increase truncation. The lysosomal stabilizing agent $\mathrm{NH}_{4} \mathrm{Cl}$ was also without effect. Incubation with the known metalloprotease collagenase did not result in enhanced truncation. In addition, incubation of the cells at $4^{\circ} \mathrm{C}$ for $4 \mathrm{hr}$ resulted in no truncation of receptor from the Schwann cells (see Table 1). Agents that caused no inhibition of truncation had no effect on cell surface LNGFR content (see Fig. $4 B$ ). Inhibition of truncation by bathophenanthroline was also evident in Schwann cells that were metabolically labeled with ${ }^{35} \mathrm{~S}$-cysteine, indicating that both labeling procedures yielded similar results (Fig. 5).

Phenanthroline or bathophenanthroline had no effects on the immunoprecipitation assay: if labeled LNGFR or NGF-Rt samples were spiked with $1 \mathrm{~mm}$ phenanthroline or bathophenanthroline at the time of the 192-IgG addition or of the Pansorbin addition, no effect on the signal was observed in the autoradiograms (data not shown). Truncation of LNGFR occurs in C6 glioma cells, JS-1 schwannoma cells, PC12 cells, and A875 melanoma cells. Phenanthroline and bathophenanthroline completely blocked truncation in the glial-like cell lines C6 and JS1 , but had little if any effect on PC12 or A875 cell truncation (data not shown).

To investigate whether the truncation of Schwann cell LNGFR could occur in disrupted cells, affinity-labeled membranes were prepared and incubated at $37^{\circ} \mathrm{C}$ as described in Materials and Methods. Interestingly, truncation occurred in membrane preparations to approximately the same extent as seen in whole cells (Fig. 6). As in whole Schwann cell experiments, truncation was inhibited by phenanthroline in a concentration-dependent manner, with concomitant increased membrane-associated LNGFR (Fig. 6A,B). While bathophenanthroline and 8-OHQ were also effective, inhibition of truncation in membranes was observed with EDTA and the peptide-based metalloprotease inhibitors Cbz-Gly-Phe and Ala-Ala-Phe-CMK (Fig. 6, Table 2). Phen- 
A. CELLS

B. MEDIA

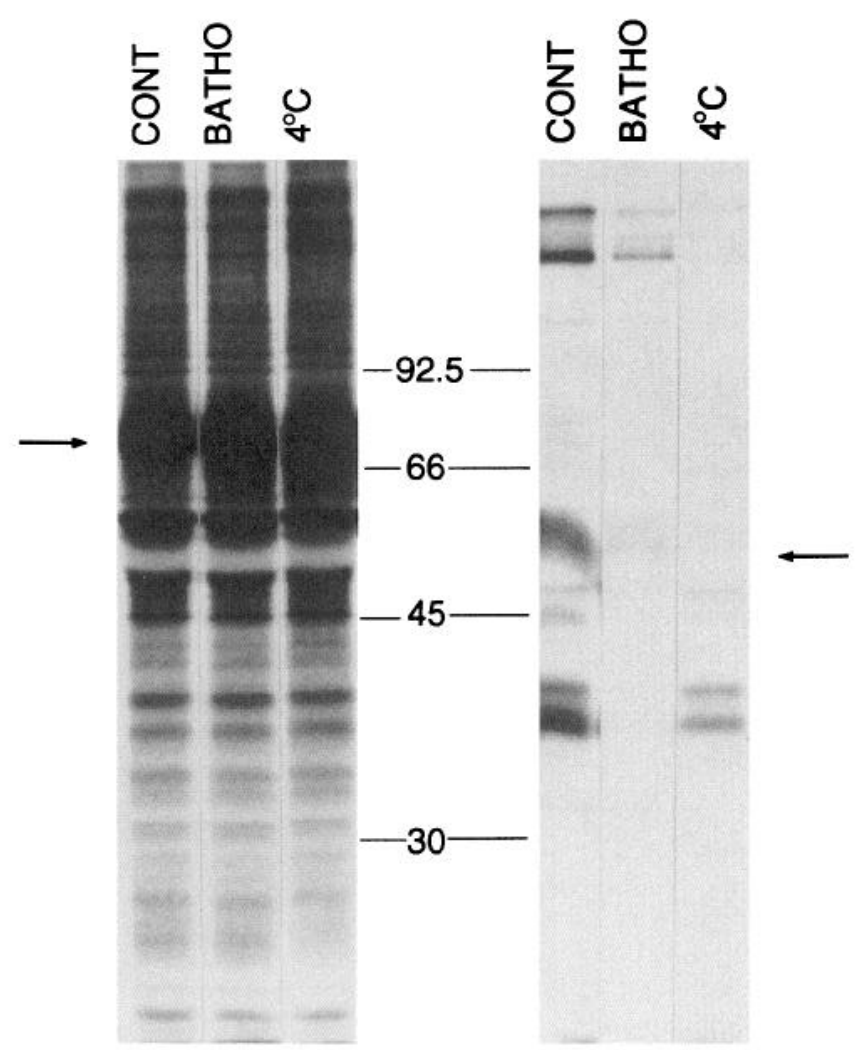

Figure 5. Effects of bathophenanthroline and $4^{\circ} \mathrm{C}$ exposure on receptor truncation in whole Schwann cells assessed by a metabolic labeling procedure. Cells were metabolically labeled and placed back in culture for $4 \mathrm{hr}$ in the presence or absence of bathophenanthroline, or at $4^{\circ} \mathrm{C}$. Immunoprecipitated samples from solubilized cells $(A)$ or conditioned media $(B)$ were separated on $10 \%$ gels and processed for fluorography. Arrows in $A$ and $B$ indicate LNGFR (broad band between 70 and 75 $\mathrm{kDa})$ and NGF-Rt (50-52 kDa), respectively. CONT, control/PBS; $B A T H O$, bathophenanthroline.

anthroline maintained a higher rank of potency compared to the other inhibitors (Table 2). DFP, PMSF, iodoacetamide, leupeptin, bestatin, and ethanol (vehicle) were without effect, corroborating the protease class specificity obtained with whole Schwann cell truncation studies. As with whole-cell experiments, truncation was completely inhibited when membranes were incubated at $4^{\circ} \mathrm{C}$.

To gain an estimation of the metal preference of the putative truncating metalloprotease investigated in this study, truncation reconstitution experiments were carried out in phenanthrolinequenched membranes (see Materials and Methods). $\mathrm{Zinc}\left(\mathrm{ZnSO}_{4}\right)$ was found to reconstitute the truncating activity to $70 \%$ of prephenanthroline treatment levels (Fig. 7). Reconstitution of truncation was also observed with $3 \times 10^{-3} \mathrm{M} \mathrm{Mn}^{2+}$ as well as $3 \times$ $10^{-3} \mathrm{M} \mathrm{Fe}^{2+}$, whereas no reconstitution was seen with $\mathrm{Ca}^{2+}$, $\mathrm{Mg}^{2+}$, or $\mathrm{Cu}^{2+}$, the only other ions tested. These findings strengthen the notion that the truncating activity is a metalloprotease and that the enzyme prefers zinc.

From the foregoing experiments it appears that a metalloprotease plays a critical role in the cleavage of Schwann cell LNGFR to NGF-Rt. To address questions concerning inhibition of Schwann cell LNGFR truncation during development
Table 1. Effects of protease inhibitors and other treatments on LNGFR truncation in Schwann cells

\begin{tabular}{llc} 
Treatment & Concentration & NGF-Rt $(\% \text { Cont. })^{a}$ \\
\hline Control & - & $99.9 \pm 0.2$ \\
Phenanthroline & $1 \times 10^{-3} \mathrm{M}$ & $8.2 \pm 4.8^{* *}$ \\
& $1 \times 10^{-4} \mathrm{M}$ & $48.5 \pm 7.0^{*}$ \\
& $1 \times 10^{-5} \mathrm{M}$ & $79.2 \pm 2.7$ \\
Bathophenanthroline & $1 \times 10^{-3} \mathrm{M}$ & $25.5 \pm 4.7^{* *}$ \\
8-OHQ & $1 \times 10^{-3} \mathrm{M}$ & 34.0 \\
EDTA & $1 \times 10^{-3} \mathrm{M}$ & $99.0 \pm 12.0$ \\
Cbz-Gly-Phe & $3 \times 10^{-3} \mathrm{M}$ & $178.4 \pm 24.7$ \\
Ala-Ala-Phe-CMK & $3 \times 10^{-3} \mathrm{M}$ & $181.8 \pm 19.9$ \\
Phosphoramidon & $1 \times 10^{-5} \mathrm{M}$ & 93.0 \\
Thiorphan & $1 \times 10^{-5} \mathrm{M}$ & 137.6 \\
DFP & $1 \times 10^{-3} \mathrm{M}$ & $106.0 \pm 1.3$ \\
PSMF & $1 \times 10^{-3} \mathrm{M}$ & 84.2 \\
Iodoacetamide & $1 \times 10^{-3} \mathrm{M}$ & $152.3 \pm 7.5$ \\
NH ${ }_{4} \mathrm{Cl}$ & $1 \times 10^{-2} \mathrm{M}$ & 101.1 \\
Ethanol & $1 \%$ & $95.6 \pm 7.1$ \\
Collagenase & $10 \mu \mathrm{g} / \mathrm{ml}^{\circ}$ & 100.8 \\
$4^{\circ} \mathrm{C}$ & - & $0.7 \pm 0.7^{* *}$
\end{tabular}

${ }^{a}$ Values represent the mean percentage of control $\pm \mathrm{SE}$ for three to six determinations. Where no errors are given, values represent one or two determinations. In most experiments two control samples were included.

${ }^{*}, p<0.05,{ }^{* *}, p<0.01$, compared to control (ANOVA)

and regeneration, studies were carried out to determine (1) if receptor truncation could be inhibited in vivo and (2) if inhibition of truncation in vivo affected nerve regeneration events, given the hypothesis that Schwann cells express LNGFR to bind NGF (or other neurotrophins), thus presenting neurotrophic factor to regenerating neurons. From the group of metalloprotease inhibitors that blocked truncation in vitro it was found that rats tolerated repeated doses of 8 -OHQ but not of phenanthroline or bathophenanthroline. Thus, initial studies were conducted to examine the ability of 8-OHQ to block truncation in neonatal rats, addressing the specific question: can 8-OHQ treatment decrease the amount of NGF-Rt found in urine and blood and increase the level of LNGFR on Schwann cells of peripheral nerve? Neonates were chosen for study, as the levels of LNGFR in sciatic nerve are relatively high and decline sharply over the first several postnatal days. Similarly, the levels of urine and plasma NGF-Rt decline rapidly over the same time course. Therefore, the first 4 postnatal days provide a good period in which to examine fluctuations in LNGFR and NGF$\mathrm{Rt}$ in rat pups treated with and without 8 -OHQ. Figure 8 shows that neonatal rat sciatic nerve LNGFR content, expressed as percentage femtomoles of ${ }^{125} \mathrm{I}-\mathrm{NGF}$ cross-linked/mg tissue protein, was unchanged at doses of 25 and $50 \mathrm{mg} / \mathrm{kg} 8-\mathrm{OHQ}$, but was significantly elevated at 75 and $100 \mathrm{mg} / \mathrm{kg}$ of the inhibitor. Urinary NGF-Rt was significantly decreased in rats treated with $75 \mathrm{mg} / \mathrm{kg}$ 8-OHQ; plasma levels of NGF-Rt were also decreased at $50 \mathrm{mg} / \mathrm{kg}$. These results show that truncation can be inhibited in vivo by 8 -OHQ.

To test whether inhibition of LNGFR truncation could have functional implications we addressed the following question: if LNGFR truncation is blocked in vivo during the course of a nerve regeneration event, will this augment the rate of regeneration, presumably by Schwann cells providing a better environment for axonal growth? The rate of sensory neuron regen- 

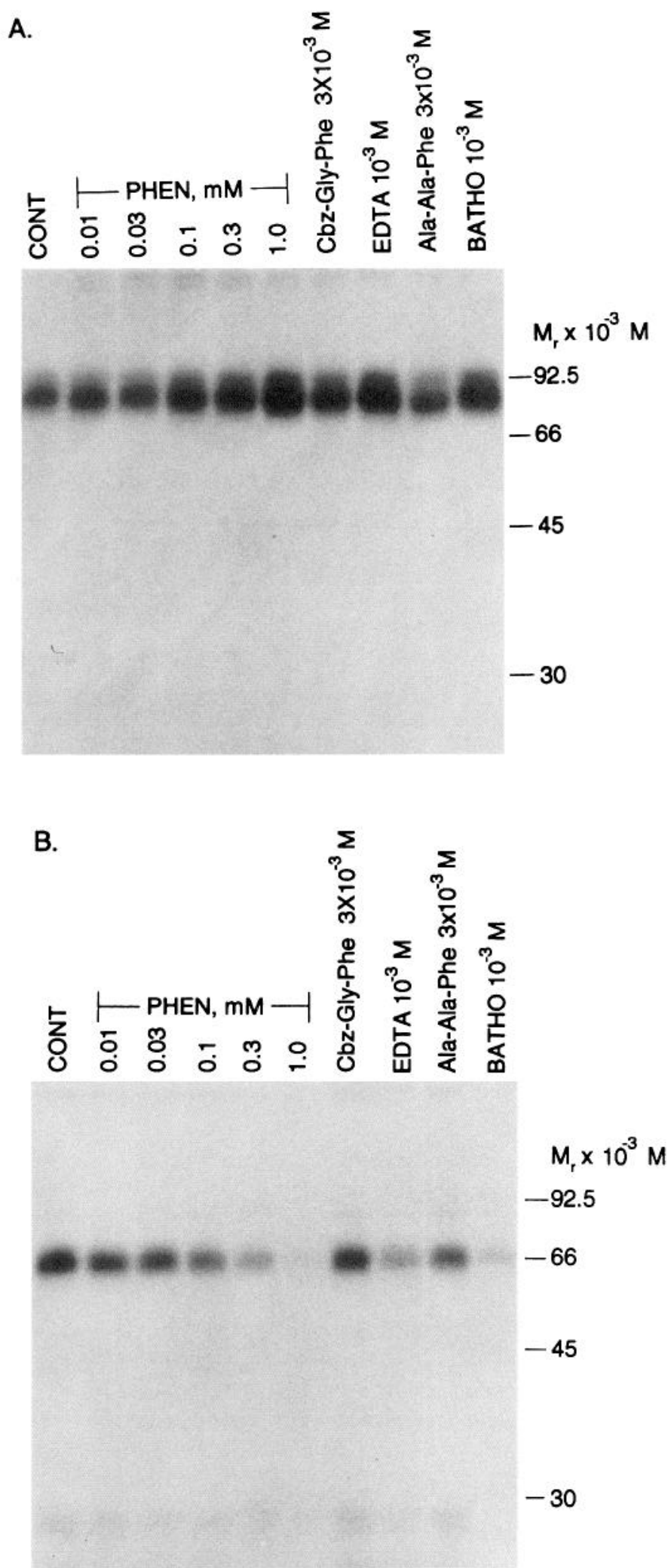

Figure 6. Effects of protease inhibitors on NGF receptor truncation in Schwann cell membranes. Membranes were prepared from ${ }^{125}$ I-NGFlabeled Schwann cells and incubated in PBS/BSA in the absence or presence of varying concentrations of protease inhibitors from various classes. Solubilized membrane LNGFR $(A)$ or conditioned media NGF$\mathrm{Rt}(B)$ samples were separated on $10 \%$ acrylamide gels. Molecular weight markers are to the right. Results are representative of three to six experiments. PHEN, phenanthroline; Ala-Ala-Phe, Ala-Ala-Phe-CMK; $B A T H O$, bathophenanthroline.
Table 2. Effect of protease inhibitors and other treatments on LNGFR truncation in Schwann cell membranes

\begin{tabular}{llc} 
Treatment & Concentration & NGF-Rt $(\% \text { Cont. })^{a}$ \\
\hline Control & - & 100 \\
Phenanthroline & $1 \times 10^{-3} \mathrm{M}$ & $12.8 \pm 2.4^{* *}$ \\
Bathophenanthroline & $1 \times 10^{-3} \mathrm{M}$ & $23.4 \pm 5.6^{* *}$ \\
8-OHQ & $1 \times 10^{-3} \mathrm{M}$ & $18.3 \pm 10.9^{*}$ \\
EDTA & $1 \times 10^{-3} \mathrm{M}$ & $29.9 \pm 2.7^{* *}$ \\
Cbz-Gly-Phe & $1 \times 10^{-3} \mathrm{M}$ & $62.5 \pm 6.2^{*}$ \\
Ala-Ala-Phe-CMK & $3 \times 10^{-3} \mathrm{M}$ & $64.4 \pm 2.9^{*}$ \\
Phosphoramidon & $1 \times 10^{-4} \mathrm{M}$ & $108.2 \pm 10.3$ \\
Thiorphan & $1 \times 10^{4} \mathrm{M}$ & $100.4 \pm 9.9$ \\
DFP & $1 \times 10^{-3} \mathrm{M}$ & $96.4 \pm 0.8$ \\
PSMF & $1 \times 10^{-3} \mathrm{M}$ & $88.2 \pm 2.5$ \\
Iodoacetamide & $1 \times 10^{-3} \mathrm{M}$ & $104.4 \pm 8.0$ \\
Ethanol & $1 \%$ & 102.7 \\
Leupeptin & $1 \times 10^{-3} \mathrm{M}$ & 110.4 \\
Bestatin & $1 \times 10^{-3} \mathrm{M}$ & 91.8 \\
4 $^{\circ} \mathrm{C}$ & - & 0
\end{tabular}

Values represent the mean percentage of control \pm SE of three to six determinations except where no errors are given $(n=1$ or 2$)$.

${ }^{*}, p<0.05,^{* *}, p<0.01$, compared to control (ANOVA).

eration in rats treated with or without 8-OHQ was monitored at various times after a crush lesion using the nerve pinch test (see Materials and Methods). It was found that $8-\mathrm{OHQ}(50 \mathrm{mg} /$ $\mathrm{kg}$ ) enhanced the distance of sensory neuron regeneration at 2 , 3,6 , and $8 \mathrm{~d}$ postlesion (not shown). Figure 9 shows that $8-\mathrm{OHQ}$ enhanced regeneration rate in a dose-dependent fashion at $3 \mathrm{~d}$ following the lesion. This occurred at doses comparable to those that inhibited truncation in neonatal rats. Consistent with results

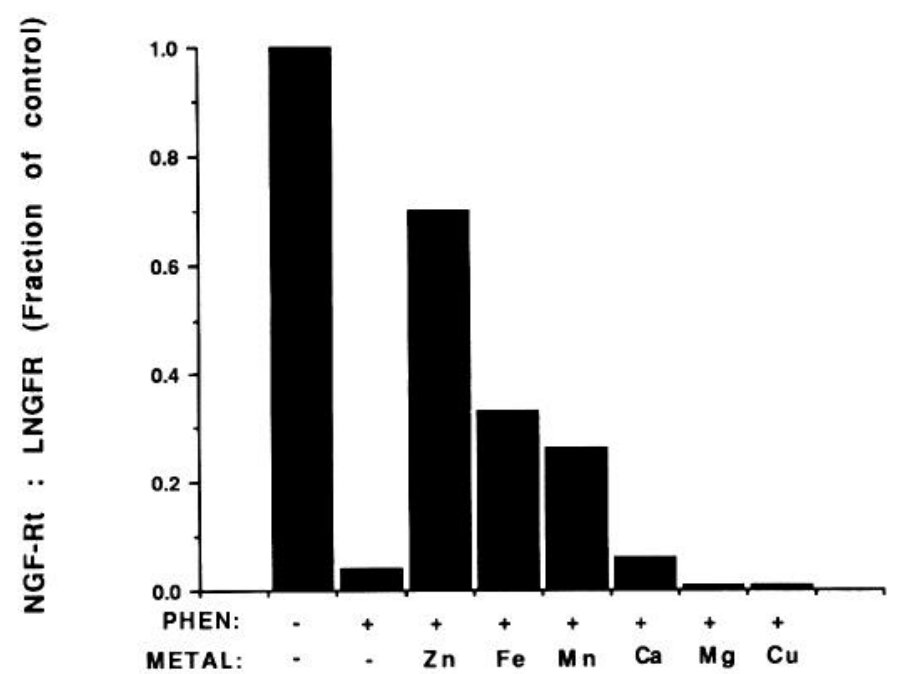

Figure 7. Effects of various metals on reconstitution of LNGFR truncation in phenanthroline-treated Schwann cells. ${ }^{125} \mathrm{I}-\mathrm{NGF}$-labeled membranes were prepared and incubated on ice for $3 \mathrm{hr}$ in the presence or absence of $1 \times 10^{-3} \mathrm{M}$ phenanthroline in PBS/BSA. Membranes were washed with cold PBS/BSA and centrifuged at $50,000 \times g$ for $20 \mathrm{~min}$. Membranes were resuspended in the presence or absence of $3 \times 10^{-3}$ M metals as either the sulfate or chloride salts (indicated at bottom) and truncation was allowed to proceed for $4 \mathrm{hr}$. Membrane LNGFR and medium NGF-Rt were assayed by SDS-PAGE as described in Materials and Methods. Results are expressed as the ratio of NGF-Rt:LNGFR, quantified densitometrically, for the various treatments. Results are representative of two experiments. 


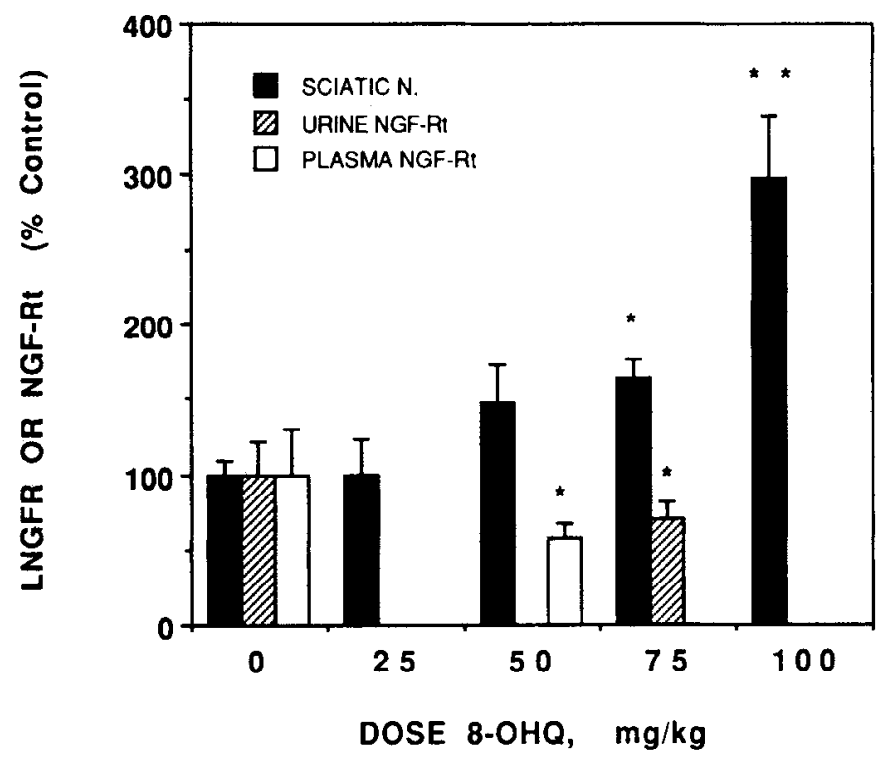

Figure 8. Dose-response of 8-OHQ on neonatal sciatic nerve LNGFR, and on urinary and plasma NGF-Rt. 8-OHQ was injected subcutaneously three times daily at doses of $0,25,50,75$, and $100 \mathrm{mg} / \mathrm{kg}$ in P1 rats. Three days later $(\mathrm{P} 4)$ rats were killed and a uniform $1.0 \mathrm{~cm}$ segment of right and left sciatic nerves (SCIATIC N.) was taken and assayed for LNGFR content. Pooled urines and heparinized plasma samples $(n=$ 3-4) were assayed for NGF-Rt and quantified densitometrically as described in Matcrials and Mcthods. In all treatment groups, littermates served as controls. Results are expressed as mean percentage of vehicletreated littermates $(0 \mathrm{mg} / \mathrm{kg}$ group $) \pm \mathrm{SE}$ for three to nine animals. Control values for sciatic nerve LNGFR ranged from 3.9 to $8.4 \mathrm{fmol}$ of ${ }^{125}$ I-NGF cross-linked/mg nerve protein. ${ }^{*}, p<0.05 ;{ }^{* *}, p<0.01$ (ANOVA).

in the neonate, $8-\mathrm{OHQ}(100 \mathrm{mg} / \mathrm{kg})$ increased LNGFR levels in distal nerve 2.5-fold compared to vehicle (Table 3). 8-OHQ also increased LNGFR levels in unlesioned (contralateral) nerve by 2.5 -fold. Thus, the increased levels of LNGFR in distal nerve correlate with enhanced regeneration.

\section{Discussion}

The observation that no alternatively spliced variants of LNGFR mRNA exist (Hempstead and Chao, 1989; Barker et al., 1991; Chao, 1991) implies a precursor-product relationship between LNGFR and NGF-Rt. Through the use of affinity labeling and metabolic labeling techniques, the results of the present study show that NGF-Rt is derived from cell surface LNGFR. Further, the observation that truncation occurs with either labeling

Table 3. Fffect of 8-OHQ on I NGFR levels in unlesioned and lesioned adult sciatic nerve

\begin{tabular}{lll} 
& \multicolumn{2}{l}{ LNGFR (fmol/mg protein) } \\
\cline { 2 - 3 } & Vehicle & $8-\mathrm{OHQ}(100 \mathrm{mg} / \mathrm{kg})$ \\
\hline $\begin{array}{l}\text { Unlesioned nerve } \\
\text { Lesioned nerve } \\
(4-12 \mathrm{~mm} \text { segment) }\end{array}$ & $0.25 \pm 0.10(3)$ & $0.64^{*} \pm 0.11(6)$ \\
& $1.21 \pm 0.19(5)$ & $3.25^{*} \pm 0.83(8)$
\end{tabular}

Rats were lesioned and treated with 8-OHQ or vehicle as described for Figure 9. Nerve segments $4-12 \mathrm{~mm}$ distal to the crush were removed, and frozen at $-80^{\circ} \mathrm{C}$ until assayed for LNGFR as described in Materials and Methods. Comparable length s of nerve on the contralateral (unlesioned) side were assayed for comparison. Results are mean + SF for the number indicated in parentheses.

$*, p<0.05$ versus vehicle.

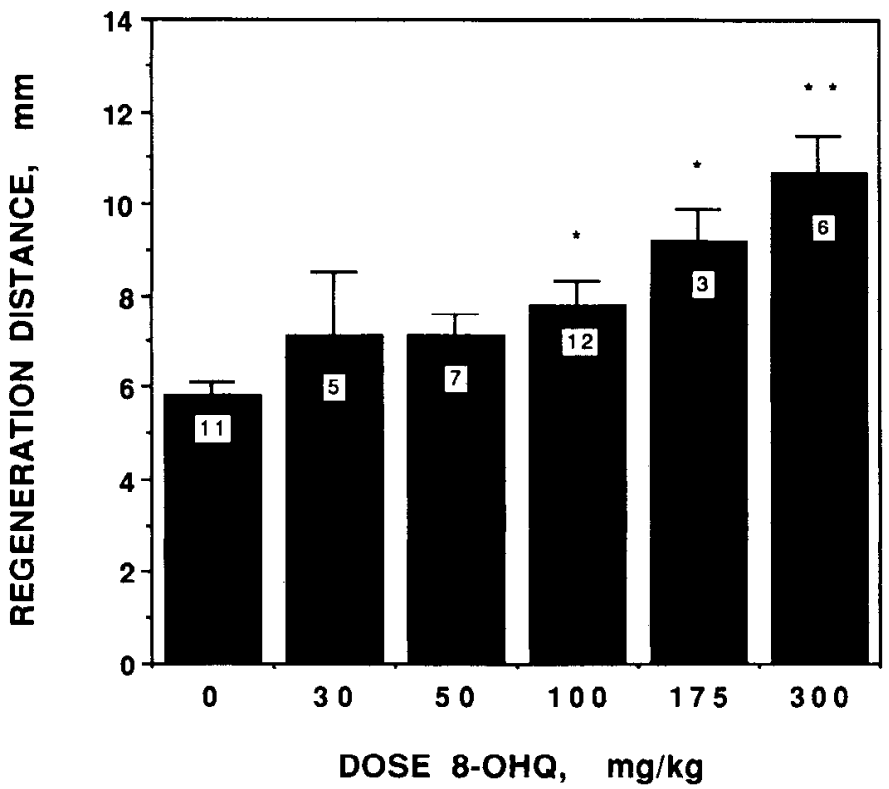

Figure 9. Dose-response of 8-OHQ on sensory neuron regeneration in adult rats receiving a sciatic nerve crush lesion. Rats were lesioned and given 8-OHQ at doses of 0 (vehicle), 30, 50, 100, 175, and 300 $\mathrm{mg} / \mathrm{kg}$ three times daily for $3 \mathrm{~d}$. The pinch test was administered on day 3 to determine the distance of regeneration. The mean regeneration distance $\pm \mathrm{SE}$ is expressed in millimeters distal to the crush site ( $n$ indicated within each bar). ${ }^{*}, p<0.05 ;{ }^{* *}, p<0.01$ versus vehicle (ANOVA).

procedure suggests that truncation is not dependent on NGF occupation of LNGFR, unlike the situation for insulin-induced and epidermal growth factor-induced cleavage of their respective cell surface receptors (Lipson et al., 1988, 1989; Decker, 1989). The results show that the culture system described, regardless of the labeling procedure, provides a reproducible and quantitative means to study the mechanisms of LNGFR truncation in Schwann cells.

Truncated forms of several single membrane-spanning cell surface receptors have been identified. In the case of the interleukin-4 (IL-4) (Mosley et al., 1989), IL-7 (Goodwin et al., 1990), and polio virus receptors (Koike et al., 1990), truncated, soluble binding sites arise from alternative splicing of receptor mRNAs. Conversely, soluble receptors for IL-2 (Rubin et al., 1985) and tumor necrosis factor (TNF) (Lantz et al., 1990; Nophar et al., 1990; Porteu et al., 1991), as well as the lymphocyte-specific glycoprotein CD27 (Loenen et al., 1992), arise from presumed proteolytic cleavage of cell surface forms. Since the type I and type II TNF receptors, CD27, and LNGFR display some structural similarities (Nophar et al., 1990; Loenen et al., 1992), the protease(s) involved in truncation of these molecules may be similar. Our results are consistent with a mechanism of proteolytic cleavage of LNGFR at or near the cell surface, rather than a mechanism involving alternatively spliced transcripts of the receptor mRNA.

The mechanism of LNGFR truncation in A875 human melanoma cells has recently been shown to occur via internalization of LNGFR, cleavage in endosomes/lysosomes, and secretion as NGF-Kt (Lupan and Johnson, 1991). This truncation mechanism is unlikely in Schwann cells since (1) the lysosomal stabilizing agent $\mathrm{NH}_{4} \mathrm{Cl}$ had no effect on truncation, (2) there is no evidence for internalization of NGF-LNGFR complexes in Schwann cells under a variety of physiological conditions (DiStefano and Johnson, 1988a), (3) if the receptor was cleaved 
intracellularly, truncated receptor should have been detectable on gel autoradiograms of cell preparations, but it was not (see Fig. 4B), and (4) Schwann cell LNGFR truncation occurs in acellular preparations, obviating lysosomal involvement. That melanoma cells (and possibly PC1 2 cells) truncate LNGFR differently from their glial counterparts (Schwann cells, C6 glioma, JS-1 schwannoma) implies different functions of LNGFR in these distinct cell types.

A major observation of the present study is that a metalloprotease-like activity is responsible for the cleavage of cell surface LNGFR to NGF-Rt in rat Schwann cells. This activity is metalloprotease-like by virtue of the fact that established metalloprotease inhibitors (phenanthroline, bathophenanthroline, 8-OHQ, EDTA) block truncation whereas inhibitors defined for other protease classes do not. Enzymatic activity is supported by the observation that no truncation occurs at $4^{\circ} \mathrm{C}$. The fact that truncation occurs in Schwann cell membrane preparations indicates that proteolytic activity is tightly associated with membranes. Further, our results show that the putative metalloprotease is active at physiological pI I and appears to favor zinc for its activity. The observation that certain water-soluble metalloprotease inhibitors were effective only in membrane preparations, coupled with the fact that exogenous substrate (LNGFR contained in SCG-CM) was cleaved by Schwann cell membranes, but not whole cells, raises the question as to whether the truncation site lies within the intracellular domain of the receptor. It is possible that the metal accessibility site is intracellular and that cleavage actually occurs on the extracellular face. The molecular weight of NGF-Rt, as determined by SDSPAGE (DiStefano and Johnson, 1988b; Zupan et al., 1989), would predict cleavage near the transmembrane domain, but exact amino acid analysis of the new C-terminus, formed by truncation, is needed to resolve the cleavage site.

The nature of the metalloprotease involved in LNGFR truncation is unknown. The enzyme is probably not the known metalloendopeptidase enkephalinase (EC 3.4.24.11), sincc the enkephalinase inhibitors thiorphan and phosphoramidon failed to block truncation in either whole-cell or membrane preparations. The putative metalloprotease appears to be moderately sensitive to the peptide-based inhibitors Cbz-Gly-Phe and AlaAla-Phe-CMK when assayed in Schwann cell membranes. The LNGFR sequence contains an Ala-Phe sequence at the end of the membrane-spanning domain, but no Gly-Phe sequence is evident in the molecule. Perhaps these peptides mimic putative cleavage sites only remotely related to the true cleavage site. The enzyme may represent a housekeeping metalloprotease that cleaves several membrane-juxtaposed proteins and receptors, or it could be glial specific and highly regulated during development and regeneration. Determining the molecular identity of this metalloprotease is critical to the understanding of its regulation and function in the axon-Schwann cell interaction.

Studics conccrning the role of LNGFR in Schwann cells suggest that the receptor is present on the Schwann cell surface to aid the developing or regenerating neurons by presenting trophic factor to the neuron (Johnson et al., 1988). The fact that Schwann cell LNGFR is downregulated by axonal contact (Yan and Johnson, 1987, 1988; Lemke and Chao, 1988; DiStefano and Chelsea, 1990) and upregulated after denervation (Taniuchi et al., 1986; Heumann et al., 1987a) supports this model. The question then arises as to the significance of LNGFR truncation in peripheral glia. We have previously postulated that NGF-Rt may serve a secondary function when liberated from the cell surface, such as a sink that regulates endogenous neurotrophin levels, a transporter of neurotrophins, a cell signaling messenger, or a substrate-interactive molecule (DiStefano and Johnson, 1988b). An alternative explanation may be that truncation represents a mechanism by which the Schwann cell eliminates a particular cell surface protein that is no longer required for cell-cell interaction in development. Stated another way, once the developing axon uses the NGF-LNGFR substratum, the cell requires a mechanism to dispose of it; otherwise, the axon will be attracted to this environment, impeding proper development.

In the situation of regeneration, where Schwann cell LNGFR expression recapitulates development, if increased amounts of receptor exist on Schwann cells, regenerative events may be more efficient. To test whether creating an LNGFR-rich environment may have beneficial effects during regeneration of peripheral neurons, we administered the relatively nontoxic metalloprotease inhibitor 8-OHQ to neonates and adult rats with sciatic nerve lesions and found that Schwann cell LNGFR could be regulated in vivo by 8-OHQ. Further, 8-OHQ treatment augmented the ratc of sensory neuron regeneration, presumably by inhibition of Schwann cell LNGFR truncation (and subsequent increased levels of cell surface receptor) in regenerating nerve. Alternatively, enhanced regeneration may have resulted from inhibition of metalloproteases involved in neuritic outgrowth of sensory neurons (Pittman, 1985). The hypothesis that LNGFR binds neurotrophins for presentation to developing and regenerating neurons hinges upon a source of neurotrophin in developing or injured nerve to bind LNGFR. It is established that sciatic nerve NGF mRNA and NGF protein (potentially reaching local concentrations in the nanomolar range) as well as brainderived neurotrophic factor (BDNF) $\mathrm{mRNA}$ levels are increased in distal sciatic nerve following a cut or crush lesion (Heumann et al., 1987a,b; Meyer et al., 1992). Further, LNGFR binds other members of the neurotrophin family (BDNF, neurotrophin-3, and neurotrophin-4) with affinities comparable to that for NGF (Hallböök et al., 1991; Squinto et al., 1991), providing the potential for Schwann cell surface LNGFR to present these factors to subsets of sensory neurons, as well as to motor and sympathetic neurons.

In summary, our results show that a membrane-associated, zinc metalloprotease activity cleaves LNGFR on Schwann cells to NGF-Rt. The results of this study demonstrate a biological significance of NGF receptor truncation, such that blockade of truncation (by inhibition of the putative metalloprotease) results in enhanced peripheral sensory nerve regeneration. We propose that receptor truncation is a novel means by which Schwann cells regulate LNGFR. Identification of the metalloprotease, as well as the truncation site on the LNGFR molecule, will allow for more specific and less toxic inhibitors of truncation to be modeled that can be tested for their potential in the treatment of peripheral nerve regeneration and peripheral neuropathy.

\section{References}

Anton ES, Matthew WD (1992) A novel function for the NGF and NGF receptors expressed on Schwann cells: a role in Schwann cell migration. Soc Neurosci Abstr 18:615.

Barker PB, Miller FD, Large TH, Murphy RA (1991) Generation of the truncated form of the nerve growth factor receptor by rat Schwann cells. Evidence for post-translational processing. J Biol Chem 266: 19113-19119.

Chandler CE, Parsons LM, Hosang M, Shooter EM (1984) A monoclonal antibody modulates the interaction of nerve growth factor with PC12 cells. J Biol Chem 259:6882-6889.

Chao MV (1991) The membrane receptor for nerve growth factor. 
Curr Topics Microbiol Immunol 165:39-53.

Decker SJ (1989) Epidermal growth factor-induced truncation of the epidermal growth factor receptor. J Biol Chem 264:17641-17644.

DiStefano PS, Chelsea DM (1990) Regulation of Schwann cell surface and truncated nerve growth factor receptors in vitro by axonal components. Brain Res 534:340-344.

DiStefano PS, Johnson EM (1988a) Nerve growth factor receptors on cultured rat Schwann cells. J Neurosci 8:231-241.

DiStefano PS, Johnson EM (1988b) Identification of a truncated form of the nerve growth factor receptor. Proc Natl Acad Sci USA 85:270274.

DiStefano PS, Clagett-Dame M, Chelsea DM, Loy R (1991) Developmental regulation of human truncated nerve growth factor receptor. Ann Neurol 29:13-20.

Goodwin RG, Friend D, Ziegler SF, Jerzy R, Falk BA, Gimpel S, Cosman D, Dower SK, March CJ, Namen AE, Park LS (1990) Cloning of the human and murine interleukin-7 receptors: demonstration of a soluble form and homology to a new receptor superfamily. Cell 60 : 941-951.

Hallböök F, Ibáñez C, Persson H (1991) Evolutionary studies of nerve growth factor family reveal a novel member abundantly expressed in Xenopus ovary. Neuron 6:845-858.

Hempstead BL, Chao MV (1989) The nerve growth factor receptor: biochemical and structural analysis. Rec Prog Horm Res 45:441-466.

Heumann R, Lindholm D, Bandtlow C, Meyer M, Radeke MJ, Misko TP, Shooter E, Thoenen H (1987a) Differential regulation of mRNA encoding nerve growth factor and its receptor in rat sciatic nerve during development, degeneration, and regeneration: role of macrophages. Proc Natl Acad Sci USA 84:8735-8739.

Heumann R, Korsching S, Bandtlow C, Thoenen H (1987b) Changes of nerve growth factor synthesis in nonneuronal cells in response to sciatic nerve transection. J Cell Biol 104:1623-1631.

Johnson EM, Taniuchi M, DiStefano PS (1988) Expression and possible function of nerve growth factor receptors on Schwann cells. Trends Neurosci 11:299-304.

Koike S, Horie H, Ise I, Okitsu A, Yoshida M, Iizuka N, Takeuchi K, Takegami T, Nomoto A (1990) The poliovirus receptor protein is produced both as membrane-bound and secreted forms. EMBO J 9:3217-3224.

Lantz M, Gullberg U, Nilsson E, Olsson I (1990) Characterization in vitro of a human tumor necrosis factor-binding protein. A soluble form of a tumor necrosis factor receptor. J Clin Invest 86:1396-1402.

Lemke G, Chao M (1988) Axons regulate Schwann cell expression of the major myelin and NGF receptor genes. Development 102:499504.

Lipson KE, Kolhatkar AA, Donner DB (1988) Cell surface proteolysis and down-regulation of the hepatic insulin receptor. Evidence for selective sorting of intact and degraded receptors after internalization. J Biol Chem 263:10495-10501.

Lipson KE, Kolhatkar AA, Donner DB (1989) Insulin stimulates proteolysis of the $\alpha$-subunit, but not the $\beta$-subunit, of its receptor at the cell surface in rat liver. Biochem J 261:333-340.

Loenen WAM, De Vries E, Gravestein LA, Hintzen RQ, Van Lier RAW Borst J (1992) The CD27 membrane receptor, a lymphocyte-specific member of the nerve growth factor receptor family, gives rise to a soluble form by protein processing that does involve receptor endocytosis. Eur J Immunol 22:447-455.

Marchalonis JJ (1969) An enzymic method for the trace iodination of immunoglobulins and other proteins. Biochem J 113:299-305.
McQuarrie IG, Grafstein B, Gershon MD (1977) Axonal regeneration in the rat sciatic nerve: effect of a conditioning lesion and of dbcAMP. Brain Res 132:443-453.

Meyer M, Matsouka I, Wetmore C, Olson L, Thoenen H (1992) Enhanced synthesis of brain-derived neurotrophic factor in the lesioned peripheral nerve: different mechanisms are responsible for the regulation of BDNF and NGF mRNA. J Cell Biol 119:45-54

Mosley B, Beckmann MP, March CJ, Idzerda RL, Gimpel SD VandenBos T, Friend D, Alpert A, Anderson D, Jackson J, Wignall JM, Smith C, Gallis B, Sims JE, Urdal D, Widmer MB, Cosman D, Park LS (1989) The murine interleukin-4 receptor: molecular cloning and characterization of secreted and membrane forms. Cell 59 . 335-348.

Nophar Y, Kemper O, Brakebush C, Engelmann H, Zwang R, Aderka D, Holtmann H, Wallach D (1990) Soluble forms of tumor necrosis factor receptors (TNF-Rs). The cDNA for the type I TNF-R, cloned using amino acid sequence data of its soluble form, encodes both the cell surface and a soluble form of the receptor. EMBO J 9:3269-3278.

Pittman RN (1987) Release of plasminogen activator and a calciumdependent metalloprotease from cultured sympathetic and sensory neurons. Dev Biol 110:91-101.

Porteu F, Brockhaus M, Wallach D, Engelmann H, Nathan CF (1991) Human neutrophil elastase releases a ligand-binding fragment from the 75-kDa tumor necrosis factor (TNF) receptor. Comparison with the proteolytic activity responsible for shedding of TNF receptors from stimulated neutrophils. J Biol Chem 266:18846-18853.

Rubin LA, Kurman CC, Fritz ME, Biddison WE, Boutin B, Yarchoan R, Nelson DL (1985) Soluble interleukin-2 receptors are released from activated human lymphoid cells in vitro. J Immunol 135:31723177.

Squinto SP, Stitt TN, Aldrich TH, Davis S, Bianco SM, Radziejewski C, Glass DJ, Masiakowski P, Furth ME, Valenzuela DM, DiStefano PS, Yancopoulos GD (1991) trkB encodes a functional receptor for brain-derived neurotrophic factor and neurotrophin-3 but not nerve growth factor. Cell 65:885-893.

Taniuchi M, Clark HB, Johnson EM (1986) Induction of nerve growth factor receptors in Schwann cells after axotomy. Proc Natl Acad Sci USA 83:4094-4098.

Yan Q, Johnson EM (1987) A quantitative study of the developmental expression of nerve growth factor (NGF) receptor in rats. Dev Biol 121:139-148.

Yan Q, Johnson EM (1988) An immunohistochemical study of the nerve growth factor (NGF) receptor in developing rats. J Neurosci 8:3481-3498

Yip HK, Johnson EM (1983) Retrograde transport of nerve growth factor in lesioned goldfish retinal ganglion cells. J Neurosci 3:21722182.

Young JZ, Medawar PB (1940) Fibrin suture of peripheral nerves. Measurement of the rate of regeneration. Lancet 2:126-128.

Zupan AA, Johnson EM (1991) Evidence for endocytosis-dependent proteolysis in the generation of soluble truncated nerve growth factor receptors by A875 human melanoma cells. J Biol Chem 266:1538415390 .

Zupan AA, Osborne PA, Smith CE, Siegel NR, Leimgruber RM, Johnson EM (1989) Identification, purification, and characterization of truncated forms of the nerve growth factor receptor. J Biol Chem 264:11714-11720 